\title{
The role of the Francisco Javier Clavijero Botanic Garden (Xalapa, Veracruz, Mexico) in the conservation of the Mexican flora
}

\author{
El papel del Jardín Botánico Francisco Javier Clavijero \\ (Xalapa, Veracruz, México) en la conservación de la flora \\ mexicana
}

Acta Botanica Mexicana

\author{
Milton H. Díaz-Toribio',3 (D), Victor Luna' (iD), Andrew P. Vovides² (iD
}

\begin{abstract}
:
Background and Aims: There are approximately 3000 botanic gardens in the world. These institutions cultivate approximately six million plant species, representing around 100,000 taxa in cultivation. Botanic gardens make an important contribution to ex situ conservation with a high number of threatened plant species represented in their collections. To show how the Francisco Javier Clavijero Botanic Garden (JBC) contributes to the conservation of Mexican flora, we asked the following questions: 1) How is vascular plant diversity currently conserved in the JBC?, 2) How well is this garden performing with respect to the Global Strategy for Plant Conservation (GSPC) and the Mexican Strategy for Plant Conservation (MSPC)?, and 3) How has the garden's scientific collection contributed to the creation of new knowledge (description of new plant species)?

Methods: We used data from the JBC scientific living collection stored in BG-BASE. We gathered information on species names, endemism, and endangered status, according to national and international policies, and field data associated with each species.

Key results: We found that $12 \%$ of the species in the JBC collection is under some risk category by international and Mexican laws. Plant families with the highest numbers of threatened species were Zamiaceae, Orchidaceae, Arecaceae, and Asparagaceae. We also found that Ostrya mexicana, Tapirira mexicana, Oreopanax capitatus, O. echinops, and $O$. xalapensis are highly threatened species representative of cloud forest currently in the collection. Conclusions: The conservation and scientific utility of the JBC collection is reflected in the exceptional accession data and the description of 24 new plant species. Having a significant number of threatened plant species in its ex situ collection, the JBC contributes to the implementation of the GSPC, particularly Target 8, as well as the implementation of the MSPC.
\end{abstract}

Key words: documented living collections, ex situ collections, horticulture, threatened species.

Resumen:

Antecedentes y Objetivos: Hay aproximadamente 3000 jardines botánicos en el mundo. Estas instituciones cultivan aproximadamente seis millones de especies de plantas, lo que representa alrededor de 100,000 taxones en cultivo. Los jardines botánicos hacen una contribución importante a la conservación ex situ con un número significativo de especies de plantas amenazadas representadas en sus colecciones. Para mostrar la contribución del Jardín Botánico Francisco Javier Clavijero (JBC) a la conservación de la flora mexicana nos planteamos las siguientes preguntas: 1) ¿Cómo se conserva actualmente la diversidad vegetal en el JBC? 2) ¿Qué tan bien se está desempeñando el jardín con respecto a la Estrategia Global para la Conservación de Plantas (GSPC) y la Estrategia Mexicana para la Conservación Vegetal (MSPC)?, y 3) ¿Cómo ha contribuido la colección científica del jardín a la creación de conocimiento (descripción de especies nuevas)?

Métodos: Utilizamos datos de la colección científica de JBC almacenados en BG-BASE. Recopilamos información sobre nombres de especies, endemismos, estatus de conservación por políticas nacionales e internacionales y datos de campo asociados a cada especie.

Resultados clave: Encontramos que $12 \%$ de toda la colección se encuentra bajo alguna categoría de riesgo según leyes internacionales y mexicanas. Las familias de plantas con especies más amenazadas fueron Zamiaceae, Orchidaceae, Arecaceae y Asparagaceae. También encontramos que Ostrya mexicana, Tapirira mexicana, Oreopanax capitatus, $O$. echinops y $O$. xalapensis son especies altamente amenazadas representativas del bosque nuboso actualmente en la colección.

Conclusiones: La conservación y utilidad científica de la colección del JBC se refleja en la calidad de datos asociados a cada especie. Además, se ha utilizado para la descripción de 24 nuevas especies de plantas. Teniendo un número significativo de especies amenazadas en su colección ex situ, el JBC contribuye a la implementación de la GSPC, particularmente al objetivo ocho, así como a la implementación de la MSPC.

Palabras clave: colecciones ex situ, colecciones vivas documentadas, especies amenazadas, horticultura.

${ }^{1}$ Instituto de Ecología, A.C., Jardín Botánico Francisco Received: October 7, 2020. Javier Clavijero, Carretera Antigua a Coatepec \#351, El Reviewed: January 5, 2021. Haya, 91073 Xalapa, Veracruz, Mexico. Instituto de Ecología, A.C., Red de Biología Evolutiva, Carretera Antigua a Coatepec \#351, El Haya, 91073 Xalapa, Veracruz, Mexico.

${ }^{3}$ Author for correspondence: milton.diaz@inecol.mx
Accepted by Marie-Stéphanie Samain: March 19, 2021.

Published Online first: April 7, 2021

Published: Acta Botanica Mexicana 128 (2021).

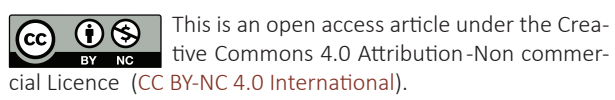

To cite as: Díaz-Toribio, M. H., V. Luna and A. Vovides. 2021. The role of the Francisco Javier Clavijero Botanic Garden (Xalapa, Veracruz, Mexico) in the conservation of the Mexican flora. Acta Botanica Mexicana 128: e1799. DOI: https://doi.org/10.21829/ abm128.2021.1799

e-ISSN: 2448-7589 


\section{Introduction}

Habitat destruction and biodiversity loss are occurring worldwide. Approximately $12.5 \%$ of the global vascular flora is facing extinction (Brummitt et al., 2015; Robertson et al., 2020). Threatened species are typically restricted to hotspots mainly in the tropics, regions of high species richness, high level of endemism, and lack of reserves to protect species (Myers et al., 2000), as well as the presence of few botanic gardens (Westwood et al., 2020), since most botanic gardens are located in temperate regions of the northern hemisphere, but very few in the tropics. Historically, biodiversity hotspots covered approximately $12 \%$ of the earth surface, but today these areas are restricted to $1.4 \%$ (Pironon et al., 2020). Hence, there is an expectation that many species within these areas are already under some threat of extinction (Brooks et al., 2002). The protected area networks for regions of high plant diversity are insufficient in order to attain effective conservation (Parga et al., 1996). Therefore, botanic gardens as a "lifeboat" strategy represent an opportunity to achieve effective plant conservation worldwide (Chen and Sun, 2018; Smith, 2019).

Today, there are approximately 3000 botanic gardens in the world (Westwood et al., 2020). These institutions cultivate approximately six million accessions of living plants, representing around 100,000 taxa in cultivation, which represent one-third of the estimated number of vascular plant species in the world (Golding et al., 2010; Sharrock and Jones, 2011; Smith, 2019; Sharrock, 2020; Westwood et al., 2020). Botanic gardens also serve as a global repository within easy reach of the public, students, and professionals alike, for documented plant ex situ collections and associated information resources: herbaria, books, journals, and electronic databases (Aronson, 2014). Utilizing knowledge from fieldwork and ecological research, botanic gardens contribute to ensuring that restoration projects include taxonomic diversity and incorporate plants of known genetic provenances (Crane et al., 2009; Oldfield, 2011). Botanic gardens inspire, inform, and educate broad audiences. Also, they offer the opportunity to conserve plant diversity in ex situ collections and have an important role in preventing species extinctions through conservation actions (Aronson, 2014; Mounce et al., 2017).
For this work, we will outline the contribution of the Francisco Javier Clavijero Botanic Garden (JBC), an in situ botanic garden of 7.5 ha in tropical montane cloud forest in Xalapa, Veracruz, Mexico, towards plant conservation of Mexican Flora. The JBC, founded in 1977, was assessed by the Royal Botanic Gardens, Kew, during its creation and can be considered an "offspring" of Kew (Vovides et al., 2010). The JBC is an in situ regional botanic garden, devoted to local floras with an emphasis on research, conservation, education, and propagation of threatened species, a concept largely born from the 1975 Kew Conference on Conservation of Threatened Plants (Simmonds et al., 1976). The Botanic Garden is home to two important National Collections: 1) The National Cycad Collection, which is made up of 1353 specimens distributed among 57 species. In Mexico there are 61 known species of native Cycads, 93\% of the Mexican species are represented in the collection, and at least one species of the other known world genera. 2) Another important collection is the National Collection of Native Bamboos of Mexico of which 57 species are known; this collection consists of 45 species and 279 specimens. One of the main missions of the JBC is ex situ conservation of local flora and that of similar ecosystems. Education and outreach are important actions the JBC undertake owing to its close interaction with the public, that range from casual visitors for recreation to professionals and students at all scholarship levels. Like many gardens, the JBC runs courses and workshops on plant cultivation and gardening for the general public, as well as formal courses leading to diplomas. The botanic garden has outreach programs, including the assessment of rural nurseries aimed at sustainable management of ornamental cycads such as Dioon edule Lindl. and Zamia furfuracea L.f. at Monte Oscuro, Veracruz, Mexico, about $30 \mathrm{~km}$ from the garden; since 1990, this program has been extended to similar nurseries in Chiapas for additional cycad species and Chamaedorea Willd. palms (Vovides et al., 2002; 2010).

In this study, we explore how vascular plant diversity is currently conserved in the Botanic Garden and how well this is performing with respect to the Global Strategy for Plant Conservation, specifically Target 8, which calls for "at least $75 \%$ of threatened plant species in ex situ collections, preferably in the country of origin" (GSPC; BGCl 2002; Black- 
more, et al., 2011; Sharrock, 2020), as well as the Mexican Strategy for Plant Conservation (MSPC; CONABIO, CONANP and SEMARNAT, 2008). Also, we quantify the number of threatened species in the JBC and propose actions to further the research, conservation, and education work of the Botanic Garden.

\section{Materials and Methods}

\section{Data sources}

We used data from the Clavijero Botanic Garden scientific living collection stored in BG-BASE (O'Neal and Walter, 2000). We gathered information on species names, endemism, endangered status according to national and international policies, and field data (i.e., geographical coordinates, location, habitat, soil type, collection date, collector) associated with each species. We also looked in our database for scientific studies that used plant material from our collection to describe new plant species. For threatened plants, we used BGCl's ThreatSearch (BGCl, 2020). This database is the most comprehensive database of conservation assessments of plants, it also includes the official IUCN Red List of Threatened Species version 2020 (IUCN, 2020), as well as the Mexican red list (SEMARNAT, 2010). In the case of the IUCN Red List, we only searched for all threatened species listed as Critically Endangered, Endangered, and Vulnerable. Threatened species exclusively from tropical montane cloud forest were defined according to The Red List of Mexican Cloud Forest Trees (González-Espinosa et al., 2011).

\section{Data processing}

For all datasets, records were filtered to remove undescribed taxa. We interpret scientific living collections to include accessions that are maintained as part of an active cultivation cycle. We discarded records of horticultural taxa such as cultivars, due to the difficulties of taxonomic standardization, and because we were interested in biological species of wild origin. We normalized the taxonomy of records using R package Taxonstand v. 1.8 (Cayuela et al., 2012), so all taxa match an accepted or unresolved taxon listed by The Plant List v. 1.1 (The Plant List, 2013). For consistency and comparability, only species-level taxa were retained for analysis; subspecies and varieties were discarded.

\section{Results}

Overall, the JBC keeps 6222 individuals of plants with field collection information, belonging to 1009 species, 480 genera, and 152 plant families. The best-represented families are Orchidaceae, Zamiaceae, and Poaceae (133, 92, and 69 species, respectively). From all these species we have an important number of plants protected by the Mexican law NOM-059-SEMARNAT-2010 (SEMARNAT, 2010). For instance, the JBC is home of 1601 individuals of 117 species in some extinction risk category; this means that $12 \%$ of the entire collection consists of threatened species. Interestingly, plant families with more species at risk in the Botanic Garden collection are Zamiaceae, Orchidaceae, Arecaceae, and Asparagaceae $(49,13,9$, and 8 species, respectively; Fig. 1). Similarly, the JBC scientific collection has over 2048 individuals of 193 species in a threatened conservation category, according to the International Union for Conservation of Nature (IUCN, 2020), which represents $32 \%$ of the entire collection. Plant families with most threatened species were Zamiaceae, Arecaceae, and Cycadaceae (53, 5, and 4 respectively; Fig. 2). Specifically, we detected 95 highly threatened species (18 Critically Endangered, 41 Endangered, and 36 Vulnerable) of 24 botanical families in the collection (Fig. 2). The plant family with the largest number of highly threatened species was Zamiaceae (15 Critically Endangered, 22 Endangered, and 12 Vulnerable species).

Another important plant group is the endemic species collection. The JBC collection has 26 plant species endemic to Mexico and 17 species endemic to Veracruz, which represent 28 and 12\%, of the total reported, respectively. The best-represented family endemic to Mexico is Orchidaceae and the best-represented family endemic to Veracruz is Zamiaceae (five and seven species, respectively).

Mexican plant species from the tropical montane cloud forest

Our analysis revealed that only 1731 (28\%) of the 6222 individuals had associated data identifying habitat provenance (i.e., type of vegetation). Tropical cloud mountain forest, sub-evergreen medium forest, and tropical perennial rainforest are the best represented vegetation types in our collection (697, 349, and 222 individuals, respectively). At the other extreme, coastal dunes, riparian vegetation, and des- 


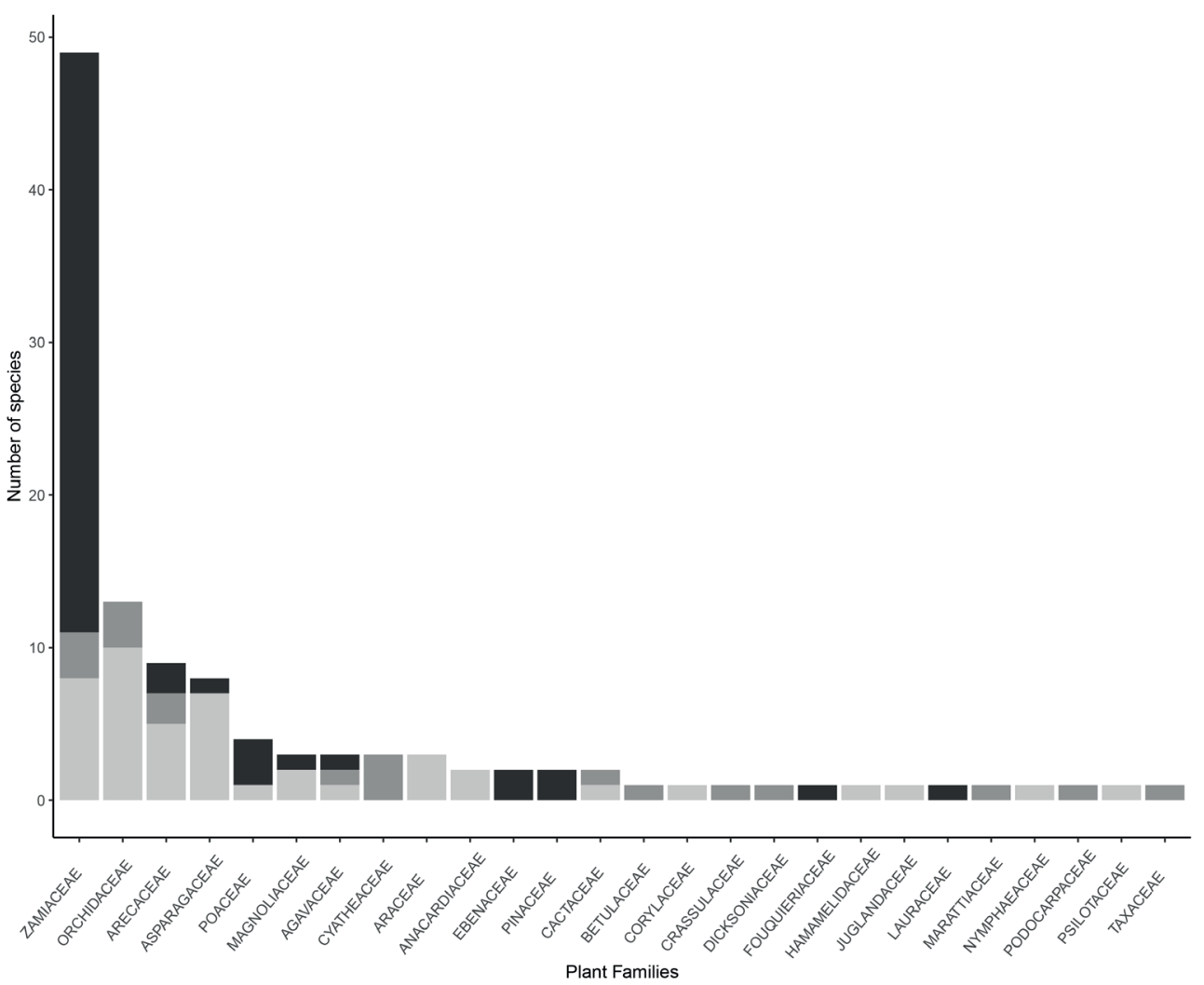

Figure 1: Number of plant families from the scientific living collection of the Francisco Javier Clavijero Botanic Garden, Xalapa, Veracruz, Mexico, with more species ( $n=117$ ) under some risk category by Mexican law (NOM-059-SEMARNAT-2010; SEMARNAT, 2010).

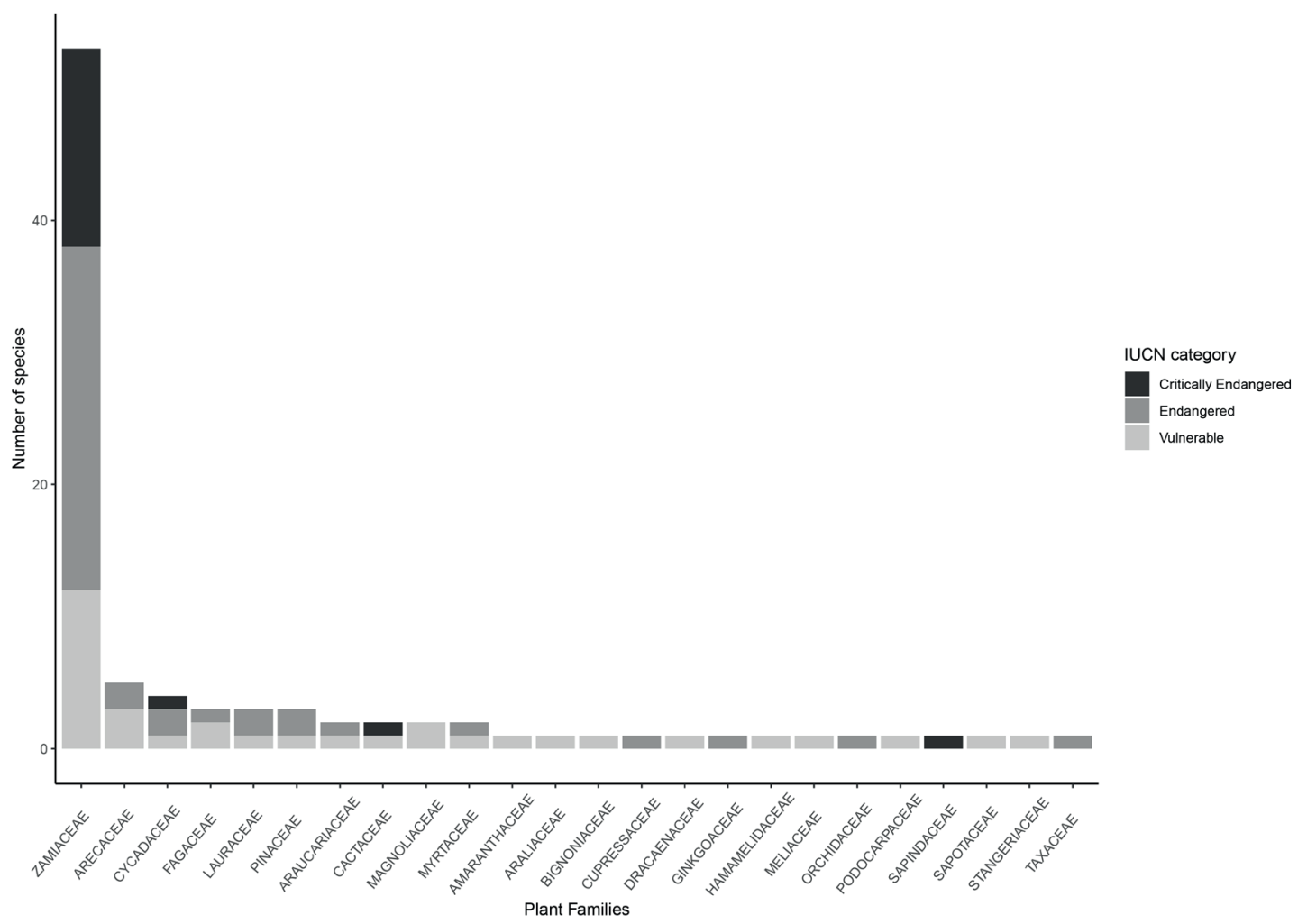

Figure 2: Number of plant families from the Francisco Javier Clavijero Botanic Garden collection, Xalapa, Veracruz, Mexico with highly threatened species ( $n=95$ ) according to the IUCN Red List (IUCN, 2020). 
sert are ecosystems with low numbers of individuals (19, six, and two, respectively).

According to the Red List of Mexican Cloud Forest Trees (González-Espinosa et al., 2011), 60 species in the scientific collection of the JBC are represented by 456 specimens classified as Endangered. For instance, Ostrya virginiana (Mill.) K. Koch (Betulaceae), Tapirira mexicana Marchand (Anacardiaceae), Oreopanax capitatus (Jacq.) Decne. \& Planch. var. capitatus (Araliaceae), O. echinops (Schltdl. \& Cham.) Decne. \& Planch., and O. xalapensis (Kunth) Decne. \& Planch. are threatened tree species representative of the cloud forest ecosystem, which are currently in the collection. In contrast, Quercus crassifolia Bonpl. (Fagaceae), Q. Iaurina Bonpl., Clethra mexicana DC. (Clethraceae), Palicourea padifolia (Roem. \& Schult.) C.M. Taylor \& Lawrence (Rubiaceae), and Alnus acuminata Kunth (Betulaceae) are cloud forest species of Least Concern (Table 1).

\section{Discussion}

The Francisco Javier Clavijero Botanic Garden (JBC) has the horticultural ability to maintain a living plant collection of a diverse taxonomic and ecological composition, mainly accumulated through wild collections and exchanges with other botanic gardens. Our results showed that the best represented plant groups in our collection are Orchidaceae and Zamiaceae. As a result, JBC has almost $50 \%$ of Mexican cloud forest orchids and has the most important Cycad collection in Mexico and perhaps in Latin America (Vovides et al., 2014). Caballero et al. (2012) reported that the Instituto de Biología Botanic Garden (Mexico City, Mexico), The Botanic Garden "Xiitbal Neek" (Yucatán, Mexico) and the JBC were the top three Mexican botanic gardens with most documented species held in their collections (1122, 1037, and 743 species, respectively). These results suggest that the JBC scientific collection constitutes an important reservoir of germplasm for species conservation. Also, this collection fulfills the function of protecting species with some degree of threat in their country of origin as specified under the GSPC. In this sense, Oldfield (2011) highlights the importance of Botanic Gardens in the conservation of plant species and emphasizes the need for spaces that represent their natural habitat. Similarly, Chen et al. (2018) point out the relevance of in situ botanical gardens to promote conservation and restoration initiatives.

The traditional collection role has emphasized taxonomic diversity to serve the classical functions of systematic, ecological research, teaching, and public display. The conservation and scientific utility of the JBC collection is reflected in the exceptional accession data and the description of 24 new plant species. For instance, Ceratozamia alvarezii Pérez-Farr., Vovides Iglesias, a new species from Chiapas, Mexico (Perez-Farrera et al., 1999), Stromanthe popolucana Cast.-Campos, Vovides \& Vázq. Torres (Castillo-Campos et al., 1998), and Chusquea enigmatica Ruiz-Sanchez, Mejía-Saulés \& Clark (Ruiz-Sanchez et al., 2014) were new species described using plant material from the National Collections of the Botanic Garden.

We assessed progress towards achieving the Global Strategy for Plant Conservation, (GSPC) specifically Target 8, which calls for "at least $75 \%$ of threatened plant species in ex situ collections, preferably in the country of origin" (Heywood and Iriondo, 2003; Callmander, et al., 2005; Blackmore et al., 2011). Surprisingly, our results showed that, currently, the JBC collection is home to $32 \%$ of Mexican plant species assessed as threatened by IUCN; although a representative number, there is potential to hold a greater proportion of threatened species. In a global Botanic Garden assessment, Mounce et al. (2017) revealed that a global network of Botanic Gardens holds $41 \%$ of threatened plant species. Despite the good representation of threatened species in the JBC collection, larger conservation-based population samples of specific groups (e.g., cycads and highly threatened cloud forest species) should be maintained ex situ to provide the necessary genetic diversity for viable conservation and restoration programs (Cibrian-Jaramillo et al., 2013; Christe et al., 2014; Griffith et al., 2015). These iconic plant groups - cycads and cloud forest species - represent taxonomic and regional priorities for the JBC conservation program. In order to capture a high proportion of genetic diversity of these imperiled species in our ex situ collection, we will implement seed banking using conventional freezer conditions recommended by the FAO (FAO, 2014; O'Donnell and Sharrock, 2017; Walters and Pence, 2020).

To advance towards an effective accomplishment of the GSPC and the Mexican Strategy for Plant Conservation, 
Table 1: Tropical cloud montane forest threatened species in the Francisco Javier Clavijero Botanic Garden collection, Xalapa, Veracruz, Mexico. Risk categories in the NOM-059-SEMARNAT-2010 (SEMARNAT, 2010) are as follows: $\mathrm{P}=$ Protected, $\mathrm{SP}=$ Special protection, and T = Threatened. Risk categories for the IUCN red list (IUCN, 2020): CR = Critically Endangered, E = Endangered, and V = Vulnerable.

\begin{tabular}{|c|c|c|c|c|}
\hline Plant family & Species & $\begin{array}{l}\text { Number of } \\
\text { individuals }\end{array}$ & $\begin{array}{c}\text { NOM-059- } \\
\text { SEMARNAT-2010 }\end{array}$ & IUCN \\
\hline \multicolumn{5}{|l|}{ Threatened species } \\
\hline Adoxaceae & Viburnum microcarpum Schltdl. \& Cham. & 5 & & \\
\hline Adoxaceae & Viburnum tiliifolium (Oerst.) Hemsl. & 2 & & \\
\hline Anacardiaceae & Spondias radlkoferi Donn. Sm. & 19 & & \\
\hline Anacardiaceae & Tapirira mexicana Marchand & 12 & & \\
\hline Araliaceae & Oreopanax capitatus (Jacq.) Decne. \& Planch. & 4 & & \\
\hline Araliaceae & Oreopanax echinops Decne. \& Planch. & 4 & & V \\
\hline Araliaceae & Oreopanax xalapensis (Kunth) Decne. \& Planch. & 1 & SP & \\
\hline Betulaceae & Ostrya virginiana (Mill.) K. Koch, & 9 & & \\
\hline Buxaceae & Buxus moctezumae Eg. Kohler, R. Fernández \& Zamudio & 10 & & \\
\hline Betulaceae & Carpinus caroliniana Walter & 8 & $\mathrm{~T}$ & \\
\hline Ebenaceae & Diospyros riojae Gómez Pompa & 6 & $\mathrm{P}$ & \\
\hline Ericaceae & Vaccinium leucanthum Schltdl. & 2 & & \\
\hline Fabaceae & Cercis canadensis $\mathrm{L}$. & 1 & & \\
\hline Fabaceae & Cojoba arborea (L.) Britton \& Rose & 6 & & \\
\hline Fagaceae & Quercus candicans Née & 8 & & \\
\hline Fagaceae & Quercus corrugata Hook. & 9 & & \\
\hline Fagaceae & Quercus germana Schltdl. \& Cham. & 8 & & V \\
\hline Fagaceae & Quercus insignis M. Martens \& Galeotti & 17 & & $\mathrm{E}$ \\
\hline Fagaceae & Quercus sartorii Liebm. & 8 & & \\
\hline Fagaceae & Quercus xalapensis Bonpl. & 13 & & $\mathrm{~V}$ \\
\hline Garryaceae & Garrya laurifolia Hartw. ex Benth. & 1 & & \\
\hline Hamamelidaceae & Matudaea trinervia Lundell & 3 & $\mathrm{~T}$ & V \\
\hline Icacinaceae & Oecopetalum mexicanum Greenm. \& C.H. Thomps. & 4 & & \\
\hline Juglandaceae & Juglans mollis Engelm. & 4 & & \\
\hline Juglandaceae & Juglans pyriformis Liebm. & 3 & $\mathrm{~T}$ & \\
\hline Lauraceae & Beilschmiedia mexicana (Mez) Kosterm. & 5 & & \\
\hline Lauraceae & Cinnamomum effusum (Meisn.) Kosterm. & 25 & & \\
\hline Lauraceae & Licaria capitata (Schltdl. \& Cham.) Kosterm. & 4 & & \\
\hline Lauraceae & Litsea glaucescens Kunth & 4 & $\mathrm{P}$ & \\
\hline Lauraceae & Nectandra reticulata (Ruiz \& Pav.) Mez & 3 & & \\
\hline Lauraceae & Nectandra salicifolia (Kunth) Nees & 35 & & \\
\hline Lauraceae & Ocotea disjuncta Lorea-Hern. & 3 & & \\
\hline Lauraceae & Ocotea helicterifolia (Meisn.) Hemsl. & 23 & & \\
\hline Lauraceae & Ocotea psychotrioides Kunth & 12 & & \\
\hline Lauraceae & Ocotea puberula (Rich.) Nees & 1 & & \\
\hline Lauraceae & Ocotea subalata Lundell & 3 & & \\
\hline Lauraceae & Persea americana Mill. & 8 & & \\
\hline Lauraceae & Persea liebmannii Mez & 5 & & \\
\hline Lauraceae & Persea longipes (Schltdl.) Meisn. & 28 & & $\mathrm{E}$ \\
\hline Lauraceae & Persea schiedeana Nees & 10 & & $\mathrm{E}$ \\
\hline Magnoliaceae & Magnolia dealbata Zucc. & 4 & $\mathrm{P}$ & \\
\hline Magnoliaceae & Magnolia mexicana DC. & 3 & $\mathrm{~T}$ & V \\
\hline Magnoliaceae & Magnolia schiedeana Schltdl. & 2 & $\mathrm{~T}$ & V \\
\hline Melastomataceae & Conostegia volcanalis Standl. \& Steyerm. & 3 & & \\
\hline Myrtaceae & Calyptranthes schlechtendaliana O. Berg & 1 & & \\
\hline Myrtaceae & Eugenia mexicana Steud. & 19 & & $\mathrm{~V}$ \\
\hline Myrtaceae & Eugenia xalapensis (Kunth) DC. & 1 & & \\
\hline Picramniaceae & Picramnia xalapensis Planch. & 1 & & \\
\hline Pinaceae & Abies hickelii Flous \& Gaussen & 2 & $\mathrm{P}$ & $\mathrm{E}$ \\
\hline
\end{tabular}


Table 1: Continuation.

\begin{tabular}{|c|c|c|c|c|}
\hline Plant family & Species & $\begin{array}{l}\text { Number of } \\
\text { individuals }\end{array}$ & $\begin{array}{c}\text { NOM-059- } \\
\text { SEMARNAT-2010 }\end{array}$ & IUCN \\
\hline Pinaceae & Abies religiosa (Kunth) Schltdl. \& Cham. & 1 & & \\
\hline Pinaceae & Pinus ayacahuite C. Ehrenb. ex Schltdl. & 4 & & \\
\hline Pinaceae & Pinus chiapensis (Martínez) Andresen & 3 & & \\
\hline Platanaceae & Platanus mexicana Moric. & 12 & & \\
\hline Podocarpaceae & Podocarpus matudae Lundell & 5 & SP & V \\
\hline Sabiaceae & Meliosma alba (Schltdl.) Walp. & 1 & & \\
\hline Sapindaceae & Acer skutchii Rehder & 11 & & $\mathrm{CR}$ \\
\hline Staphyleaceae & Turpinia insignis (Kunth) Tul. & 25 & & \\
\hline Styracaceae & Styrax glabrescens Benth. & 14 & & \\
\hline Taxaceae & Taxus globosa Schltdl. & 2 & SP & $\mathrm{E}$ \\
\hline Ulmaceae & Ulmus mexicana (Liebm.) Planch. & 6 & & \\
\hline \multicolumn{5}{|c|}{ Species of Least Concern } \\
\hline Betulaceae & Alnus acuminata Kunth & 8 & & \\
\hline Cecropiaceae & Cecropia obtusifolia Bertol. & 1 & & \\
\hline Clethraceae & Clethra mexicana DC. & 8 & & \\
\hline Clusiaceae & Clusia salvinii Donn. Sm. & 1 & & \\
\hline Fabaceae & Inga jinicuil Schltdl. & 3 & & \\
\hline Fabaceae & Inga vera Willd. & 3 & & \\
\hline Fagaceae & Quercus laurina Bonpl. & 9 & & \\
\hline Fagaceae & Quercus crassifolia Bonpl. & 3 & & \\
\hline Lauraceae & Cinnamomum triplinerve (Ruiz \& Pav.) Kosterm. & 7 & & \\
\hline Lauraceae & Ocotea veraguensis (Meisn.) Mez & 9 & & \\
\hline Melastomataceae & Conostegia xalapensis D. Don & 1 & & \\
\hline Meliaceae & Trichilia havanensis Jacq. & 4 & & \\
\hline Myrsinaceae & Ardisia compressa Kunth & 20 & & \\
\hline Myrtaceae & Eugenia capuli Schltdl. & 30 & & \\
\hline Myrtaceae & Eugenia acapulcensis Steud. & 10 & & \\
\hline Oleaceae & Fraxinus uhdei Lingelsh. & 6 & & \\
\hline Pinaceae & Pinus montezumae Lamb. & 1 & & \\
\hline Pinaceae & Pinus patula Schltdl. \& Cham. & 3 & & \\
\hline Piperaceae & Piper auritum Kunth & 2 & & \\
\hline Rosaceae & Crataegus mexicana Moc. \& Sessé ex DC. & 1 & & \\
\hline Rubiaceae & Palicourea padifolia (Roem. \& Schult.) C.M. Taylor \& Lorence & 5 & & \\
\hline Salicaceae & Xylosma flexuosa (Kunth) Hemsl. & 2 & & \\
\hline Solanaceae & Cestrum aurantiacum Lindl. & 1 & & \\
\hline Sterculiaceae & Guazuma ulmifolia Lam. & 1 & & \\
\hline Ulmaceae & Trema micrantha (L.) Blume & 1 & & \\
\hline Verbenaceae & Citharexylum mocinnoi D. Don & 1 & & \\
\hline
\end{tabular}

the JBC was recently supported by The National Council on Science and Technology of Mexico (CONACYT) to create a new Ethnobiology display area. This new display area will exhibit a collection of species used in traditional medicine and local culinary plants from central Veracruz. Also, this space will contribute to the rescue of traditional, indigenous, rural, and urban knowledge associated with regional edible plants, bamboos (used in construction and handicraft production), cycads that reach high prices in the ornamental market, and products derived from the hives of native bees, widely valued in traditional medicine and as nutritional supplements.

In summary, the JBC has a unique opportunity to contribute to the Global Strategy for Plant Conservation and the Mexican Strategy for Plant Conservation. It is a center for a valuable and distinctive range of staff skills, including the capacity to engage and educate the public, it is well networked 
among Mexican Botanic Gardens and with other conservation organizations.

\section{Author contributions}

MHDT and APV co-conceived the study; MHDT wrote the manuscript and analyzed the data; VL helped with data curation; MHDT, APV, and VL revised and completed the manuscript. All authors contributed critically to the drafts and approved the final version for publication.

\section{Funding}

This work was supported by the Consejo Nacional de Ciencia y Tecnología (CONACYT-FORDECYT-PRONACES) through the project: “Un jardín etnobiológico: Ampliando los horizontes del Jardín Botánico Francisco Javier Clavijero en Xalapa, Veracruz" (grant number 305103).

\section{Acknowledgements}

We thank the Francisco Javier Clavijero Botanic Garden staff (C. Iglesias) for all the hard work to maintain the Botanic Garden Collection. We thank J. L. Aguilar, anonymous reviewers and editors for helpful comments on earlier drafts of the manuscript.

\section{Literature cited}

Aronson, J. 2014. The ecological restoration alliance of botanic gardens: A new initiative takes root. Restoration Ecology 22(6): 713-715. DOI: https://doi.org/10.1111/rec.12151

BGCl. 2002. Global Strategy for Plant Conservation. Botanical Garden Conservation International. Islas Canarias, Spain. 13 pp.

BGCl. 2020. ThreatSearch online database. Botanic Gardens Conservation International. https://www.bgci.org/threat search.php (consulted May, 2020).

Blackmore, S., M. Gibby and D. Rae. 2011. Strengthening the scientific contribution of botanic gardens to the second phase of the Global Strategy for Plant Conservation. Botanical Journal of the Linnean Society 166(3): 267-281. DOI: https://doi. org/10.1111/j.1095-8339.2011.01156.x

Brooks, T. M., R. A. Mittermeier, C. G. Mittermeier, G. A. B. Da Fonseca, A. B. Rylands, W. R. Konstant, P. Flick, J. Pilgrim, S. Oldfield, G. Magin and C. Hilton-Taylor. 2002. Habitat loss and extinction in the hotspots of biodiversity. Conservation Biology 16(4): 909923. DOI: https://doi.org/10.1046/j.1523-1739.2002.00530.x
Brummitt, N. A., S. P. Bachman, J. Griffiths-Lee, M. Lutz, J. F. Moat, A. Farjon, J. S. Donaldson, C. Hilton-Taylor, T. R. Meagher, S. Albuquerque, E. Aletrari, A. K. Andrews, G. Atchison, E. Baloch, B. Barlozzini, A. Brunazzi, J. Carretero, M. Celesti, H. Chadburn, E. Cianfoni, C. Cockel, V. Coldwell, B. Concetti, S. Contu, V. Crook, P. Dyson, L. Gardiner, N. Ghanim, H. Greene, A. Groom, R. Harker, D. Hopkins, S. Khela, P. Lakeman-Fraser, H. Lindon, H. Lockwood, C. Loftus, D. Lombrici, L. Lopez-Poveda, J. Lyon, P. Malcolm-Tompkins, K. McGregor, L. Moreno, L. Murray, K. Nazar, E. Power, M. Q. Tuijtelaars, R. Salter, R. Segrott, H. Thacker, L. J. Thomas, S. Tingvoll, G. Watkinson, K. Wojtaszekova and E. M. N. Lughadha. 2015. Green plants in the red: A baseline global assessment for the IUCN Sampled Red List Index for Plants. PLoS ONE 10(8): 1-22. DOI: https://doi.org/10.1371/journal.pone.0135152

Caballero, N. J. 2012. Jardines botánicos: Contribución a la conservación vegetal de México. Comision Nacional para el Conocimiento y Uso de la Biodiversidad. Mexico, D.F., México. 183 pp.

Callmander, M. W., G. E. Schatz and P. P. Lowry. 2005. IUCN Red List assessment and the Global Strategy for Plant Conservation: Taxonomists must act now. Taxon 54(4): 1047-1050. DOI: https://doi.org/10.2307/25065491

Castillo-Campos, G., A. P. Vovides and M. Vázquez. 1998. Una nueva especie de Stromanthe (Marantaceae) de Veracruz, Mexico. Polibotanica 8: 13-19.

Cayuela, L., Í. Granzow-de la Cerda, F. S. Albuquerque and D. J. Golicher. 2012. Taxonstand: An r package for species names standardisation in vegetation databases. Methods in Ecology and Evolution 3(6): 1078-1083. DOI: https://doi. org/10.1111/j.2041-210x.2012.00232.x

Chen, G. and W. Sun. 2018. The role of botanical gardens in scientific research, conservation, and citizen science. Plant Diversity 40(4): 181-188. DOI: https://doi.org/10.1016/j. pld.2018.07.006

Christe, C., G. Kozlowski, D. Frey, L. Fazan, S. Bétrisey, S. Pirintsos, J. Gratzfeld and Y. Naciri. 2014. Do living ex situ collections capture the genetic variation of wild populations? A molecular analysis of two relict tree species, Zelkova abelica and Zelkova carpinifolia. Biodiversity and Conservation 23: 2945-2959. DOI: https://doi.org/10.1007/s10531-014-0756-9

Cibrian-Jaramillo, A., A. Hird, N. Oleas, H. Ma, A. W. Meerow, J. Francisco-Ortega and M. P. Griffith. 2013. What is the conservation value of a plant in a botanic garden? Using indica- 
tors to improve management of ex situ collections. The Botanical Review 79: 559-577. DOI: https://doi.org/10.1007/ s12229-013-9120-0

CONABIO, CONANP and SEMARNAT. 2008. Estrategia Mexicana para la Conservación Vegetal. https://www.biodiversidad. gob.mx/media/1/planeta/internacional/files/EMCV_-_ Objetivos_y_Metas.pdf (consulted June, 2020).

Crane, P. R., S. D. Hopper, P. H. Raven and D. W. Stevenson. 2009. Plant science research in botanic gardens. Trends in Plant Science 14(11): 575-577. DOI: https://doi.org/10.1016/j. tplants.2009.09.007

FAO. 2014. Genebank standards for plant genetic resources for food and agriculture. Food and Agriculture Organization of the United Nations. Rome, Italy. Pp. 166.

Golding, J., S. Güsewell, H. Kreft, V. Y. Kuzevanov, S. Lehvävirta, I. Parmentier and M. Pautasso. 2010. Species-richness patterns of the living collections of the world's botanic gardens: A matter of socio-economics? Annals of Botany 105(5): 689696. DOI: https://doi.org/10.1093/aob/mcq043

González-Espinosa, M., J. A. Meave, F. G. Lorea-Hernández, G. Ibarra-Manríquez and A. C. Newton. 2011. The Red List of Mexican Cloud Forest Trees. Fauna and Flora International. Cambridge, UK. https://globaltrees.org/resources/red-listmexican-cloud-forest/ (consulted May, 2020).

Griffith, M. P., M. Calonje, A. W. Meerow, F. Tut, A. T. Kramer, A. Hird, T. M. Magellan and C. E. Husby. 2015. Can a botanic garden cycad collection capture the genetic diversity in a wild population? International Journal of Plant Sciences 176(1): 1-10. DOI: https://doi.org/10.1086/678466

Heywood, V. H. and J. M. Iriondo. 2003. Plant conservation: old problems, new perspectives. Biological Conservation 113(3): 321335. DOI: https://doi.org/10.1016/S0006-3207(03)00121-6

IUCN. 2020. The International Union for Conservation of Nature. Red List of Threatened Species, version 3.1. http://iucnredlist.org/ (consulted June, 2020).

Mounce, R., P. Smith and S. Brockington. 2017. Ex situ conservation of plant diversity in the world's botanic gardens. Nature Plants 3: 795-802. DOI: https://doi.org/10.1038/s41477017-0019-3

Myers, N., R. A. Mittermeier, C. G. Mittermeier, G. A. B. da Fonseca and J. Kent. 2000. Biodiversity hotspots for conservation priorities. Nature 403: 853-858. DOI: https://doi. org/10.1038/35002501
O'Donnell, K. and S. Sharrock. 2017. The contribution of botanic gardens to ex situ conservation through seed banking. Plant Diversity 39(6): 373-378. DOI: https://doi.org/10.1016/j. pld.2017.11.005

Oldfield, S. 2011. Botanic gardens and the conservation of tree species. Trends in Plant Science 14(11): 474-487. DOI: https://doi.org/10.1016/j.tplants.2009.08.013

O'Neal, M. J. and K. S. Walter. 2000. Update: BG-BASE - a tool for the 21st century. The Public Garden 15(4): 21-25.

Parga, I. C., J. C. M. Saiz, C. J. Humphries and P. H. Williams. 1996. Strengthening the Natural and National Park system of Iberia to conserve vascular plants. Botanical Journal of the Linnean Society 121(3): 189-206. DOI: https://doi. org/10.1111/j.1095-8339.1996.tb00753.x

Perez-Farrera, M. A., A. P. Vovides and C. Iglesias. 1999. A new species of Ceratozamia (Zamiaceae, Cycadales ) from Chiapas, Mexico. Novon 9(3): 410-413. DOI: https://doi. org/10.2307/3391741

Pironon, S., J. S. Borrell, I. Ondo, R. Douglas, C. Phillips, C. K. Khoury, M. B. Kantar, N. Fumia, M. Soto Gomez, J. Viruel, R. Govaerts, F. Forest and A. Antonelli. 2020. Toward unifying global hotspots of wild and domesticated biodiversity. Plants 9: 1128 (1-18). DOI: https://doi.org/10.3390/ plants9091128

Robertson, E., A. Frances, K. Havens, J. Maschinski, A. Meyer and L. Ott. 2020. Fund plant conservation to solve biodiversity crisis. Science 367(6475): 2018-2020. DOI: https://doi. org/10.1126/science.aba4360

Ruiz-Sanchez, E., T. Mejía-Saulés and L. G. Clark. 2014. A new endangered species of Chusquea (Poaceae: Bambusoideae) from the Acatlán volcano in central Veracruz, Mexico, and keys to the Mexican Chusquea species. Phytotaxa 163(1): 16-26. DOI: https://doi.org/10.11646/phytotaxa.163.1.2

SEMARNAT. 2010. Norma Oficial Mexicana NOM-059-SEMARNAT-2010. Protección ambiental-Especies nativas de México de flora y fauna silvestres-Categorías de riesgo y especificaciones para su inclusión, exclusión o cambio-Lista de especies en riesgo. Secretaría del Medio Ambiente y Recursos Naturales. Diario Oficial de la Federación. Cd. Mx., México. http://dof.gob.mx/nota_detalle.php?codigo=5173091 \&fecha $=30 / 12 / 2010$.

Sharrock, S. 2020. Plant conservation report 2020: A review of progress in implementation of the Global Strategy for Plant 
Conservation 2011-2020. Secretariat of the Convention on Biological Diversity and Botanic Gardens Conservation International. Richmond, UK.

Sharrock, S. and M. Jones. 2011. Saving Europe's threatened flora: progress towards GSPC Target 8 in Europe. Biodiversity and Conservation 20: 325-333. DOI: https://doi.org/10.1007/ s10531-010-9912-z

Simmonds, J. B., R. I. Beyer, P. E. Brandham, G. L. Lucas. and V. T. Parry. 1976. Conservation of Threatened Plants. NATO Conference Series 1: Ecology. New York and London: Plenum Press. London, UK. 336 pp.

Smith, P. 2019. The challenge for botanic garden science. Plants, People, Planet 1(1): 38-43. DOI: https://doi.org/10.1002/ ppp3.10

The Plant List. 2013. The Plant List version 1.1. http://www.theplantlist.org/ (consulted May, 2020).

Vovides, A. P., M. A. Pérez-Farrera and C. Iglesias. 2010. Cycad propagation by rural nurseries in Mexico as an alternative conservation strategy: 20 years on. Kew Bulletin 65(4): 603611. DOI: https://doi.org/10.1007/s12225-010-9240-1
Vovides, A. P., C. Iglesias, V. Luna and T. Balcázar. 2014. Los jardines botánicos y la crisis de la biodiversidad. Botanical Sciences 91(3): 239-250. DOI: https://doi.org/10.17129/botsci.5

Vovides, A. P., C. Iglesias, M. A. Pérez-Farrera, M. Vázquez Torres and U. Schippmann. 2002. Peasant nurseries: a concept for an integrated conservation strategy for cycads in Mexico. In: Maunder, M. C., C. Clubbe, C. Hankamer and M. Groves (eds.). Plant Conservation in the Tropics-perspectives and practice. Kew, The Royal Botanic Gardens. London, UK. Pp. 421-444.

Walters, C. and V. C. Pence. 2020. The unique role of seed banking and cryobiotechnologies in plant conservation. Plants, People, Planet 3(1): 83-91. DOI: https://doi.org/10.1002/ ppp3.10121

Westwood, M., N. Cavender, A. Meyer and P. Smith. 2020. Botanic garden solutions to the plant extinction crisis. Plants, People, Planet 3(1): 22-32. DOI: https://doi.org/10.1002/ ppp3.10134 